\title{
PTEN Hamartoma Tumor Syndrome: A Clinical Overview
}

\author{
Robert Pilarski (10)
}

Division of Human Genetics, Department of Internal Medicine and Comprehensive Cancer Center, The Ohio State University, Columbus, OH 43221, USA; Robert.pilarski@osumc.edu; Tel.: +1-614-293-7774;

Fax: +1-614-293-2314

Received: 9 May 2019; Accepted: 14 June 2019; Published: 18 June 2019

check for updates

\begin{abstract}
The phosphatase and tensin homolog (PTEN) hamartoma tumor syndrome (PHTS) is a grouping of related genetic disorders that has been linked to germline mutations in the PTEN gene. These disorders include Cowden syndrome (CS), Bannayan-Riley-Ruvalcaba syndrome, adult Lhermitte-Duclos disease, and autism spectrum disorders associated with macrocephaly. The majority of the clinical information available on PHTS, however, is related to individuals diagnosed with CS. There is still much to be learned about this disorder, since diagnostic criteria for CS were only established in 1996, before the identification of the PTEN gene, and were based primarily on features seen in cases reported in the existing literature. More recently, however, data from several large series of patients have shown that a number of the clinical features associated with PTEN mutations are either more or less common than previously reported. In addition, we now know that only about $30-35 \%$ of patients meeting clinical diagnostic criteria for Cowden syndrome actually have a detectable PTEN mutation. Thus, our understanding of PTEN-related diseases and their management has evolved significantly over time. The United States National Comprehensive Cancer Network (NCCN) has produced and regularly updates practice guidelines which include clinical diagnostic criteria as well as guidelines for PTEN testing and management of patients with mutations. This review will summarize the overall literature on PHTS as well as recent findings which are broadening our understanding of this set of disorders.
\end{abstract}

Keywords: PTEN; PHTS; PTEN harmartoma tumor syndrome; cowden syndrome; BannayanRuvalcaba-Riley syndrome

\section{Introduction}

PTEN hamartoma tumor syndrome (PHTS) refers to a spectrum of disorders that have been linked to germline mutations in the PTEN gene. These include Cowden syndrome, Bannayan-Riley-Ruvalcaba syndrome, adult Lhermitte-Duclos disease, and autism spectrum disorders associated with macrocephaly. The majority of the published data, however, address patients with Cowden syndrome, and risks must be extrapolated to the other conditions. To date there is insufficient evidence of a correlation between specific PTEN mutations and clinical presentations.

Cowden syndrome (CS) is a rare, multi-system disease that was first described in one family in 1963 [1]. It entails increased risks for malignancies of a number of organs (particularly breast, thyroid and endometrium) and benign overgrowth of a number of tissues (skin, colon, thyroid, etc.). Germline PTEN mutations were first reported in individuals with CS in 1997 [2,3].

Bannayan-Riley-Ruvalcaba syndrome (BRRS) is a rare pediatric disorder that was initially felt to be distinct from CS. The most common clinical features include macrocephaly, hamartomatous intestinal polyps, lipomas, and pigmented macules on the penis. Other reported features include developmental delay, vascular anomalies, large birth weight, and joint hyperextensibility [4]. BRRS 
has been shown to be allelic to CS, with approximately $60 \%$ of patients having PTEN mutations $[5,6]$. No other genes are known to cause BRRS. However, there are relatively few data on the clinical features of BRRS patients with documented PTEN mutations [7].

There is broad variability in the clinical presentation of patients with PTEN mutations, even between patients with the same mutation and patients in the same family. Indeed, families have been reported in which one or more individuals met CS diagnostic criteria while others met BRRS criteria [5,8-10]. While a clear genotype/phenotype correlation has not been shown with PTEN, there is some evidence that mutations leading to stable but inactive proteins produce a more severe phenotype than mutations leading to proteins with partially retained function [11]. Spinelli et al. reported that all seven autism-associated mutations that they studied led to proteins that retained the ability to suppress AKT signaling [12]. Studies in mice suggest that tumor presentation is dependent on the genetic background of the animal, but the implications for humans with PTEN mutations are unclear [13].

Consensus diagnostic criteria for CS were initially established in 1996 by an international research consortium. This was prior to identification of the CS gene and the criteria were based upon early clinical experience and compilations of cases published in the literature, with their inherent ascertainment biases [14]. The single largest patient series in any of these reports comprised 21 patients [15]. It was not until 2013 that an evidence-based review led to a significant revision of the diagnostic criteria (summarized in Table 1), which were then adopted by the U.S. National Comprehensive Cancer Network [16,17].

Table 1. Revised PTEN hamartoma tumor syndrome (PHTS) diagnostic criteria.

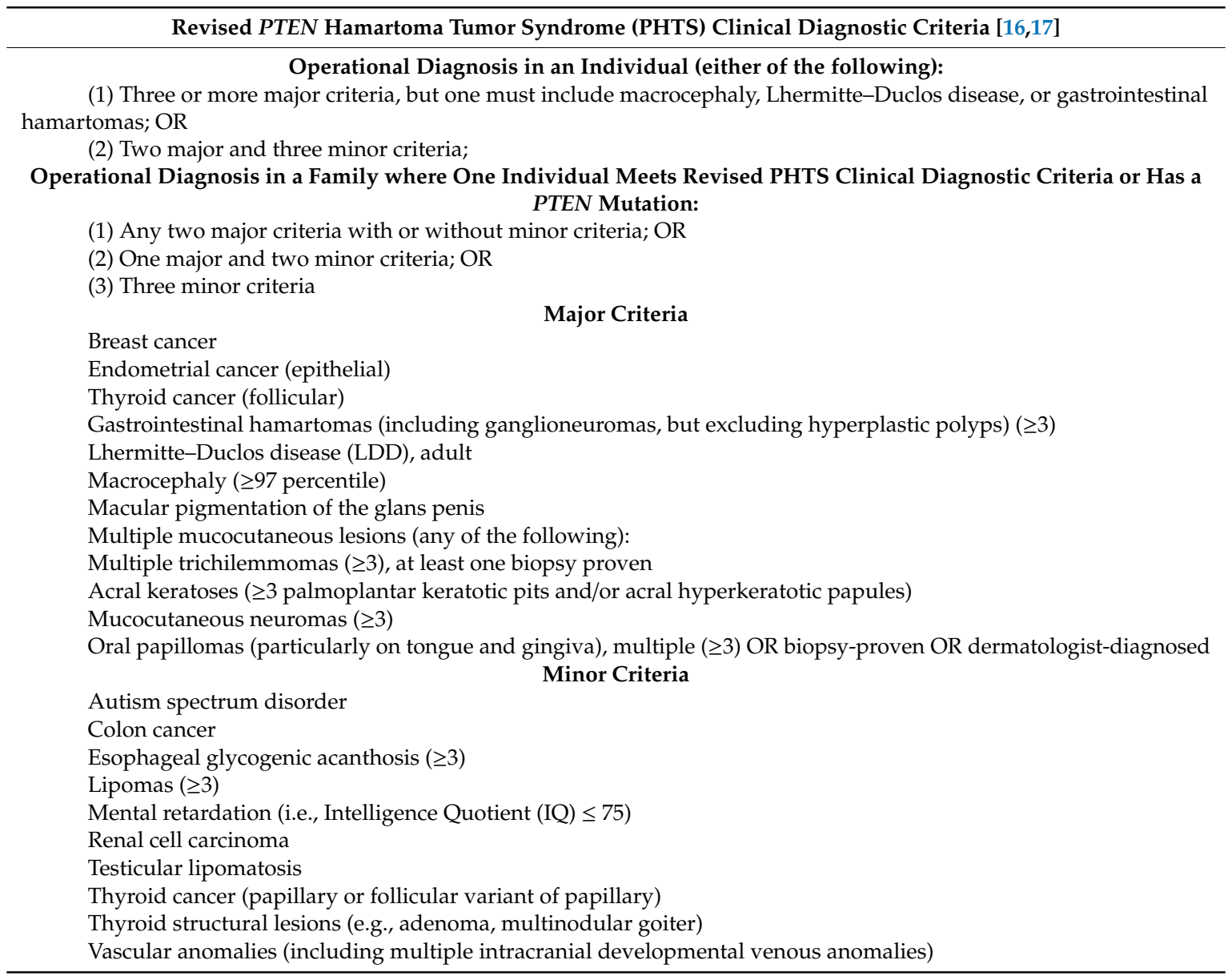

It was initially reported, based on small series, that PTEN mutations were found in $80 \%$ of patients with CS $[3,18]$. More recently, in much larger cohorts, PTEN mutations have been found in only 30-35\% 
of patients meeting consortium diagnostic criteria and in $23 / 42(55 \%)$ patients with a clinical diagnosis of BRRS [6,19]. Importantly, 63/172 (37\%) patients with mutations in one of these studies did not meet diagnostic criteria for either CS or BRRS [6]. It is estimated that at least $11 \%$, and perhaps as many as $48 \%$, of patients have de novo mutations [20].

The National Comprehensive Cancer Network (NCCN) has established criteria for when PTEN testing is indicated based on the clinical features present in a patient, as well as management and screening recommendations for individuals who are found to have a PTEN mutation [16]. As noted above, they have also adopted revised clinical diagnostic criteria since patient management is sometimes based on a clinical diagnosis alone if either testing is not possible or it is done but no mutation is found.

This paper reviews the current understanding of the clinical features that are most clearly associated with PTEN mutations.

\section{Cancer/Tumor Risks}

The risks for breast, uterine, thyroid, and colon cancer and Lhermitte-Duclos disease are clearly increased in individuals with PTEN mutations. The magnitude of these risks, however, is less certain. The association of PTEN mutations with other tumor types is less clear. Each of these is discussed further below.

\subsection{Brain Tumors}

Lhermitte-Duclos disease (LDD, dysplastic gangliocytoma of the cerebellum) is a rare, slow growing hamartoma which is usually diagnosed when patients are in their twenties or thirties. While it appears to be clearly associated with PTEN mutations, the incidence of LDD in patients with CS is unknown [21]. A prevalence of 1.8\% (3/172) was found in patients undergoing clinical PTEN testing [6], of $6 \%(18 / 290)$ in patients in a research cohort [19], and of $15 \%$ in cases reported in the literature. [22] Wei et al. found that five of seven adults with LDD had features of PHTS, although PTEN testing was not done [23]. Based on a small study of unselected LDD tumors from 15 adults and three children, it appears that adult-onset LDD is more strongly associated with PTEN mutations than childhood-onset LDD [24]. In another review of 14 children with LDD, three had clinical diagnoses of CS, eight had no signs of the disease, and three had insufficient information to determine a diagnosis [25].

While various case reports have suggested that a variety of other brain tumors are linked to PTEN mutations, the true spectrum and frequency of brain lesions is unknown since brain imaging is rarely done on asymptomatic individuals. Only one report of brain magnetic resonance imaging (MRI) in asymptomatic CS patients has been published [26]. In this study, seven of 20 patients (mean age 42 years) had brain abnormalities (including three patients with LDD): six had venous and cavernous angiomas, and one had a meningioma. Although multiple cases of meningioma have now been reported in CS (reviewed in Lok et al. [26] and Yabubov et al. [27]), no systematic study has been done and their prevalence in PHTS is unknown. Lok et al. found hamartomatous vascular malformations in almost a third of their patients [26].

\subsection{Breast Cancer}

Although initially not regarded as being part of the syndrome, breast cancer has long been recognized as the most common CS malignancy. The age of onset appears to be young (average age $38-50$ years), and the lifetime risk is typically quoted to be $25-50 \%[6,15,19,28,29]$. Several more recent reports have projected the lifetime risk of breast cancer to be $77-85 \%$ in several cohorts $[22,30,31]$. Selection bias was a significant issue in each of these studies, however, as lifetime risks were projected based on the prevalence of breast cancer in the patients who presented for testing (which typically includes those most likely to have cancer). Thus, while breast cancer risk is clearly increased in individuals with PTEN mutations, there remains debate as to the degree of that risk. Three males with PTEN mutations and breast cancer have been reported [18,32,33], but male breast cancer was not seen 
in the two largest cohorts reported to date, and a possible association with male breast cancer remains unproven $[6,19]$.

\subsection{Gastrointestinal Cancer}

Although it was originally felt that PTEN mutations did not increase the risk for colon cancer [34], more recent data has shown otherwise. Several studies have shown the prevalence of colon cancer (often early-onset) in several PTEN mutation-carrier cohorts to be 9-13\% [35,36]. Two later publications predicted lifetime colon cancer risks of 9\% (Confidence Interval (CI) 3.8-14.1\%) and 16\% (CI 8-24\%), although both were limited by ascertainment biases common in PHTS studies [22,31]. A small study from the Mayo Clinic found colon cancer in two of 13 CS patients [37].

There are at least four reports of gastric cancer in CS patients, but at this point it is not considered part of the PHTS spectrum [34,38-40].

\subsection{Endometrial Cancer}

Endometrial cancer was found in $14.1 \%$ and $7.6 \%$ of female PTEN mutation carriers in two large research series $[6,19]$, and in $17 \%$ of clinically tested adult females in another cohort, with the greatest increase in women under age 50 [6]. As noted above with breast cancer, three studies on cancer risks in PTEN mutation carriers have projected an increased lifetime risk of endometrial cancer ranging from 19 to $28 \%$ at age 70 , but each suffers from ascertainment bias [22,30,31]. Among 54 families in another study with uterine and breast cancers and at least one other PTEN-related cancer, no PTEN mutations were identified [41]. In contrast, $7 \%$ of a cohort of endometrial cancer patients with features of Cowden syndrome had PTEN mutations in another report, although it is not possible to tell from the data how many of these met CS/PHTS diagnostic criteria [42]. Among 381 endometrial cancer patients who underwent screening for Lynch syndrome, one had a PTEN mutation [43]. Among unselected case of endometrial cancer inherited PTEN mutations are quite rare [44].

\subsection{Melanoma}

Various case reports have suggested that melanoma risk may be increased in individuals with PTEN mutations [45-48]. However it was found in only about 1\% (2/172) of patients with mutations in one recent cohort, although the mean age of the cohort was only 30 years [6]. More recently, one group projected a $6 \%$ lifetime risk for melanoma (based on nine cases of melanoma reported among 368 patients with mutations) while a second projected standardized incidence ratios (SIRs) of 28.3 in women and 39.4 in men, (based on nine cases among 154 mutation-positive patients) [30,31]. The lifetime risk of developing melanoma in the United States is almost 2.8\% [49]. Given this limited evidence, melanoma is not included as a diagnostic criterion for PHTS and more data are needed regarding its association with PTEN.

\subsection{Thyroid Cancer}

Historically, the lifetime risk of thyroid cancer in PTEN mutation carriers was estimated to be $3-10 \%$ [50]. However, recent analyses of two cohorts of PTEN mutation carriers (with the same ascertainment biases noted above for other cancers) have projected lifetime risks of 35-38\% [30,31]. Whether these are significant overestimates remains to be determined. Papillary (including follicular variant) thyroid cancer represents 56-60\%, while follicular pathology accounts for $25-45 \%$ of reported cancers [51,52]. Medullary thyroid cancer is not felt to be associated with PTEN mutations.

The prevalence of PTEN mutations in unselected individuals presenting with differentiated thyroid cancer appears to be low, with only two mutations found in 259 individuals in one study. Both patients had follicular thyroid cancer and other features of PHTS such as macrocephaly. Among follicular thyroid cancer cases $2 / 42$ harbored PTEN mutations [53]. Another study found no PTEN mutations in women presenting with both primary breast and thyroid cancers [54]. 


\subsection{Renal Cell Carcinoma}

The risk for renal cell carcinoma (RCC) was initially suggested to be increased in CS based on several case reports $[55,56]$. More recent case series of patients with PTEN mutations reported RCC in $5 \%$ of 107 clinically tested adults and $3-6.7 \%$ of adults who had research testing [6,19]. Two studies recently projected the lifetime risk for RCC in individuals with PTEN mutations to be approximately $34 \%$, although these were based on small numbers of cases and may be an overestimate reflecting ascertainment bias [30,31]. In another series, four of $24(16.7 \%)$ patients with CS were found to have a total of five RCC, although none had a family history of RCC [57]. Loss of heterozygosity for PTEN was shown for four of the five tumors. Among eight PHTS patients with RCC, Mester et al. found papillary histology in six and chromophobe histology in two [58]. Immunohistochemistry showed complete loss of PTEN staining in all six papillary tumors and patchy positivity in one of the chromophobe tumors. Germline PTEN mutations are rare among individuals with non-syndromic hereditary RCC [57].

\section{Benign Disease}

As noted above, individuals with germline PTEN mutations are at risk for a range on non-malignant disease. The actual prevalence of most of these in PHTS patients, however, is difficult to determine.

\subsection{Brain Lesions}

There are limited data on the prevalence of developmental delay and mental retardation (MR/DD) among individuals with PTEN mutations. The prevalence does seem to be increased over the general population rate of $3 \%$, however, with MR/DD reported in $12 \%$ [29] and 15-20\% [59] of cases in the literature, and in $17 \%$ of 110 mutation-positive patients who underwent clinical testing [6]. It has been reported that $15-20 \%$ of patients with BRRS have mental retardation and an additional $50 \%$ may have motor and speech delays but normal adult intelligence [59]. There is a broad range of manifestation, from normal intelligence (in most), to mild-significant developmental delays/MR, to autism spectrum disorders.

Based on cases reported in the literature, macrocephaly (defined as a head circumference greater than the 97th percentile) was initially reported to be present in $40 \%$ of CS patients. It has since been found in $80-100 \%$ of patients with PTEN mutations whose head circumference had been measured, $[6,19,21,60,61]$. Macrocephaly is also seen in the majority of BRRS patients, but it is also one of the few diagnostic criteria for the condition so it would be expected to be frequently seen [59]. Hansen-Kiss et al. found macrocephaly in 46 of 47 (98\%) pediatric patients with PTEN mutations in their study [62]. Vanderver et al. reported the brain MRI findings (including enlarged perivascular spaces and multifocal periventricular white matter abnormalities) in a cohort of 23 patients with PTEN mutations and macrocephaly [63], while Ciaccio et al. found various brain abnormalities in $75 \%$ of pediatric PTEN mutation carriers who had imaging [64] and Hansen-Kiss et al. found a range of abnormalities in 53\% of 17 children with PTEN mutations who had brain imaging [62]. Balci et al. reported on nine patients with PTEN mutations and white matter changes on brain MRI who presented with a range of developmental phenotypes [65].

Germline mutations in PTEN also cause a subset of patients with both autism spectrum disorders (ASD) and macrocephaly, with patients with the largest head sizes being more likely to have a mutation [66-73]. In these reports PTEN mutations have been found in 1-27\% of patients with ASD and macrocephaly, even in absence of other personal or family history suggestive of PHTS. Some evidence suggests that PTEN mutations retaining partial function may lead to milder phenotypes such as these $[11,12,74]$. 


\subsection{Gastrointestinal Disease}

Despite initial reports that colonic polyps were found in $40 \%$ of patients with CS, recent data has shown that polyps are found in up to $95 \%$ of adults with PTEN mutations who have undergone colonoscopy [36,37]. Polyp numbers can be few or numerous (even hundreds), may sometimes occur in childhood, and are distributed throughout the colon. The range of polyp types seen includes adenomas, ganglioneuromas, hamartomas, inflammatory polyps, leiomyomas, lipomas, and lymphoid polyps $[36,50,75,76]$. Hyperplastic polyps have also been seen, but they are common in the general population and have not been observed in all studies so the association with PTEN is unclear [36,77]. The majority of CS patients have multiple synchronous histologic types at colonoscopy. Among 603 patients with five or more colon polyps (including at least one hamartomatous or hyperplastic polyp), Ngeow et al. found germline mutations in known non-adenomatous polyposis genes in $13 \%$, including PTEN mutations in 2.2\% [78]. Patients with ganglioneuromas, intramucosal lipomas, and/or those with three or more polyp types were more likely to harbor PTEN mutations [76,79]. Shaco-Levy et al. described a similar range of histologies among the polyps seen in 13 patients with CS [80]. Henderson et al. suggested that eosinophilic gastrointestinal disorders may be more common in children with PTEN mutations [81].

The esophagus in PHTS is characterized by glycogenic acanthosis [82]. One or several such lesions may occasionally be observed in unaffected individuals, but numerous and diffuse lesions were seen in the majority ( $80 \%$ or more) of CS patients in one study [77]. Although one group has recommended that diffuse esophageal glycogenic acanthosis combined with colonic polyposis should be considered pathognomonic for CS, this has not been incorporated into the NCCN diagnostic criteria [83].

Upper gastrointestinal lesions are also seen in PHTS, with multiple hamartomatous polyps in the stomach, duodenum, and small bowel reported [34,36,77,82]. These included adenomas, hamartomas, and inflammatory and hyperplastic polyps (different from colonic hyperplastic polyps), as well as ganglioneuromas.

\subsection{Skin Lesions}

A number of dermatologic lesions are common in PHTS. While initial reports (published at a time when dermatologic features were required to make a clinical diagnosis of Cowden syndrome) suggesting dermatologic lesions are present in almost $100 \%$ of CS patients are likely overestimates, it is clear that they are a common finding in individuals with PTEN mutations.

Among these, multiple trichilemmomas are most strongly indicative of a PTEN mutation. These can be seen on the face including the eyes, mouth, nose, and forehead $[15,48,84-87]$, as well as the neck, axillae, and hand [88,89]. The prevalence of trichilemmomas in individuals with a confirmed PTEN mutation ranges from 6 to $25 \%$ in large case series, with some patients presenting under 18 years of age $[3,6,19,36]$. Trichilemmomas are clinically indistinguishable from trichoepitheliomas, fibrofolliculomas, and other benign skin lesions and thus require histopathology to confirm a diagnosis $[85,86,90,91]$.

Acral keratoses, located on the palmoplantar surfaces and dorsal hands/feet, have been repeatedly reported in both children and adults with PHTS [15,29,48,88,92-94]. Acral keratoses have been noted in both pediatric and adult populations of PTEN mutation carriers, but further studies are needed to define the age of onset and penetrance $[19,36,93,95]$. Some case reports observed keratoses appearing on non-acral sites as well $[15,48]$. At this time further studies are needed to determine the penetrance and age of onset of acral keratoses in PHTS, as well as to determine if they are more common in non-acral sites as well.

Sclerotic fibromas of the skin, which are rare in the general population, have been reported in a number of case series of patients with a clinical diagnoses of Cowden syndrome prior to the identification of the PTEN gene, and in individual case reports of patients with mutations [15,96-98]. Among clinically diagnosed Cowden syndrome patients the prevalence of oral fibromas ranges between 14 and $76 \%[15,29]$. Although more common in the general population than sclerotic fibromas, the 
incidence of oral fibromas in the general population is not well defined. Further studies are needed in individuals with PTEN mutations to characterize the prevalence and natural history of both skin and oral fibromas.

Lipomas are included in the clinical diagnostic criteria for both BRRS and CS. In a prospective cohort of 43 clinically and/or genetically diagnosed BRRS cases compared to 37 Cowden syndrome families, the features of lipomas and vascular abnormalities were more commonly observed in BRRS or BRRS/Cowden syndrome overlap families [5]. The presence of multiple lipomas in an individual in the general population is rare but this has been reported in several small and large case series of individuals with a PTEN mutation. [6,15,36,48,55,88,91,93,99-103].

Mucocutaneous neuromas (hamartoma of the peripheral nerve sheath) have been reported on the face, hands, shins, and back in numerous patients with PHTS, with Starink et al. (reporting before the identification of the PTEN gene) finding them in more than half of their clinically-diagnosed patients by age $18[15,48,101,104]$. At this time further studies are needed to determine the prevalence and clinical features of neuromas seen in PHTS.

Oral papillomas, seen on the lips, tongue, buccal mucosa, and gingivae, are common in PHTS, although the florid papillomatosis shown in some publications is rare $[15,29,48,84,88,89,91,92,103,105,106]$. They typically present by the second decade of life and are usually asymptomatic, in contrast to neuromas [15,84,88,89,93,101,104].

While benign pigmentation of the genitals is reported in up to $15 \%$ of males in the general population [107], their prevalence is clearly increased in males with PTEN mutations. In one large cohort, $48 \%$ of males with either a clinical diagnosis or a PTEN mutation had significant penile freckling, while in another study, 53\% of male PTEN mutation carriers had this finding [6,19]. Hansen-Kiss et al. found penile freckling in 12/29 (41\%) of boys with PTEN mutations, the youngest at 15 months of age [62].

Vascular (venous or arterial) anomalies are reportedly common in BRRS and CS, particularly in patients with a BRRS diagnosis. A number of case reports support the association of arteriovenous malformations in clinically diagnosed BRRS patients [108-111]. Among 20 CS patients undergoing brain MRI, Lok et al. noted venous angiomas in five and cavernous angiomas in two [26]. Tan et al. reported on the vascular anomalies seen in a cohort of 23 patients with PTEN mutations, while Kurek et al., reporting on a cohort of patients with known or suspected PTEN mutations, noted a distinctive lesions they designated as a PTEN hamartoma of soft tissue [21,112]. Smaller case series have specifically reported hemangiomas and cavernous hemangiomas in both children and adults with PTEN mutations $[62,94,101,102]$. Pimpalwar et al. reported on the natural history and management of fast flow vascular anomalies in four patients [113]. In the general population, certain subtypes of hemangioma are sporadic and common in children or adults [114]. Thus, further studies are needed on the prevalence of vascular lesions in PHTS.

Testicular lipomas have only been noted in PHTS since 2003, being first reported in a 39 year-old male with multiple fat-containing testicular hamartomas [115]. Since then, Woodhouse et al. reported findings from testicular ultrasound in a series of eight males (ages 16 to 58) with documented PTEN mutations, finding multiple, bilateral hyperechoic lesions in all but the youngest patient $[116,117]$. Biopsies from four of the patients confirmed lipomas. Subsequently, multiple other cases of testicular lipomas in males with CS or BRRS have been reported [118-122]. Testicular lipomas are very rare in the general population in absence of testicular neoplasia [117], with Harper et al. finding only one case in a Medline search from 1970 to 2001 [123]. Although their prevalence in males with PTEN mutations is unknown, the presence of multiple testicular lipomas has been added to the clinical diagnostic criteria for CS/PHTS [17].

\subsection{Thyroid Disease}

Benign thyroid disease is common in PHTS, with thyroid nodules, adenoma, or goiter reported in $30-68 \%$ of adults and $2-14 \%$ of children with PTEN mutations $[6,19]$. Tan et al. reported a 
prevalence of 3-21\% specifically for Hashimoto thyroiditis in individuals with PTEN mutations [19]. Hall et al. reviewed the thyroid findings in 181 CS patients reported in the literature, with their inherent ascertainment and publication biases, and found thyroid disease reported in $53 \%$ of patients, with $80 \%$ of these requiring surgical management [124]. It should be noted that almost 38\% of these patients did not have genetic testing to confirm the presence of a PTEN mutation. Thyroid lesions are very common in the general population, which complicates efforts to determine their prevalence in PHTS. The prevalence of thyroid nodules in the general population ranges from 2 to $6 \%$ on physical exam to $19-35 \%$ on ultrasound to as high as $65 \%$ in autopsy series [125]. Multinodular goiter is found in about $4 \%$ of the population, [126] while Hashimoto's thyroiditis occurs in 2\% [127].

Hansen-Kiss et al. found abnormal thyroid imaging (cysts, nodules and goiter) in $26 \%$ of their series of 47 pediatric patients with PTEN mutations [62]. Plamper, reporting on patients seen in a pediatric endocrine clinic, found thyroid abnormalities in 12 of 16 (75\%) children with PTEN mutations in their series, with eight of them undergoing thyroidectomy [128]. Pathology varied from nodular goiter, follicular adenoma and autoimmune disease to papillary microcarcinoma in a six-year-old boy and follicular carcinoma in a 13-year-old girl.

There are limited data on the clinical features and pathology of thyroid nodules in PTEN mutation carriers. One review of thyroidectomy specimens from 20 individuals found that all had multiple findings, most commonly multinodular goiter $(75 \%)$, which was often seen along with thyroiditis (55\%) [52]. Another study of the thyroid pathology from 25 individuals with PTEN mutations had similar findings [129]. A pediatric study found thyroid nodules at as young as age 6 [130]. It is important to note the ascertainment biases in these studies, however, since most were evaluating individuals who presented with significant and overt thyroid disease, and the frequency and clinical presentation in unselected mutation carriers is unknown.

\subsection{Other Benign Diseases}

Other benign lesions such as fibrocystic and other benign breast diseases, uterine fibroids, and genito-urinary malformations were initially included in the clinical diagnostic criteria for CS. However, there is insufficient evidence to show that they are more common among individuals with PTEN mutations than in the general population (in which fibrocystic breast disease and uterine fibroids in particular are very common), and they have been dropped from the clinical diagnostic criteria [16,17]. While a range of other breast lesions (sometimes quite complex) have been reported in case reports or small series of women with clinical or molecular diagnoses of Cowden syndrome, there are no good data on unselected patient populations [131,132].

While more data are needed, a growing number of reports suggest possible immune system dysregulation in some individuals with germline PTEN mutations, as shown in mouse models [133-137]. In addition, there is evidence for the role of PTEN in metabolic regulation and for a form of constitutive insulin sensitivity in some individuals with PTEN mutations [138-141].

\section{Conclusions}

As has been shown, our understanding of the clinical and molecular features of PTEN hamartoma tumor syndrome continues to evolve. As with many rare conditions, it has been difficult to obtain data on substantial numbers of patients with PHTS. The larger patient cohorts that have been assembled suffer from significant ascertainment bias since most of the patients were tested specifically because they presented with significant clinical features of PHTS. To date, no large cohort study has been published on mutation carriers who are relatives of the probands who were initially tested (which would help reduce ascertainment bias). Unfortunately, it is unlikely that such a cohort could be assembled, and thus we must rely on the data that are available. In recent years, various publications have improved on our understanding of the prevalence of PTEN mutations, macrocephaly, and colon disease in particular in PHTS patients, and have added testicular lipomatosis and possibly immunologic problems to the PHTS phenotypic spectrum. At the same time, we have seen that the data do not 
support the inclusion of previously long-held features such as fibrocystic breast, uterine fibroid, and genito-urinary malformations. Over time we can expect to see further clarification of the phenotypes of this fascinating set of disorders.

Funding: This research received no external funding.

Conflicts of Interest: The authors declare no conflict of interest.

\section{References}

1. Lloyd, K.M.; Denis, M. Cowden's disease: A possible new symptom complex with multiple system involvement. Ann. Intern. Med. 1963, 58, 136-142. [CrossRef] [PubMed]

2. Nelen, M.R.; van Staveren, C.G.; Peeters, E.A.J.; Ben Hassel, M.; Gorlin, R.J.; Hamm, H.; Lindboe, C.F.; Fryns, J.-P.; Sijmons, R.H.; Woods, D.G.; et al. Germline mutations in the PTEN/MMAC1 gene in patients with Cowden disease. Hum. Mol. Genet. 1997, 6, 1383-1387. [CrossRef] [PubMed]

3. Liaw, D.; Marsh, D.J.; Li, J.; Dahia, P.L.M.; Wang, S.I.; Zheng, Z.; Bose, S.; Call, K.M.; Tsou, H.C.; Peacocke, M.; et al. Germline mutations of the PTEN gene in Cowden disease, an inherited breast and thyroid cancer syndrome. Nat. Genet. 1997, 16, 64-67. [CrossRef] [PubMed]

4. Gorlin, R.J.; Cohen, M.M., Jr.; Condon, L.M.; Burke, B.A. Bannayan-Riley-Ruvalcaba syndrome. Am. J. Med. Genet. 1992, 44, 307-314. [CrossRef] [PubMed]

5. Marsh, D.J.; Kum, J.B.; Lunetta, K.L.; Bennett, M.J.; Gorlin, R.J.; Ahmed, S.F.; Bodurtha, J.; Crowe, C.; Curtis, M.A.; Dazouki, M.; et al. PTEN mutation spectrum and genotype-phenotype correlations in Bannayan-Riley-Ruvalcaba syndrome suggest a single entity with Cowden syndrome. Hum. Mol. Genet. 1999, 8, 1461-1472. [CrossRef]

6. Pilarski, R.; Stephens, J.A.; Noss, R.; Fisher, J.L.; Prior, T.W. Predicting PTEN mutations: An evaluation of Cowden syndrome and Bannayan-Riley-Ruvalcaba syndrome clinical features. J. Med. Genet. 2011, 48, 505-512. [CrossRef]

7. Hendriks, Y.M.; Verhallen, J.T.; van der Smagt, J.J.; Kant, S.G.; Hilhorst, Y.; Hoefsloot, L.; Hansson, K.B.; van der Straaten, P.J.; Boutkan, H.; Breuning, M.H.; et al. Bannayan-Riley-Ruvalcaba syndrome: Further delineation of the phenotype and management of PTEN mutation-positive cases. Fam. Cancer 2003, 2, 79-85. [CrossRef]

8. Eng, C. Cowden syndrome. J. Genet. Couns. 1997, 6, 181-191. [CrossRef]

9. Celebi, J.T.; Tsou, H.C.; Chen, F.F.; Zhang, H.; Ping, X.L.; Lebwohl, M.G.; Kezis, J.; Peacocke, M. Phenotypic findings of Cowden syndrome and Bannayan-Zonana syndrome in a family associated with a single germline mutation in PTEN. J. Med. Genet. 1999, 36, 360-364.

10. Zori, R.T.; Marsh, D.J.; Graham, G.E.; Marliss, E.B.; Eng, C. Germline PTEN mutation in a family with Cowden syndrome and Bannayan-Riley-Ruvalcaba syndrome. Am. J. Med. Genet. 1998, 80, 399-402. [CrossRef]

11. Leslie, N.R.; Longy, M. Inherited PTEN mutations and the prediction of phenotype. Semin. Cell Dev. Biol. 2016, 52, 30-38. [CrossRef] [PubMed]

12. Spinelli, L.; Black, F.M.; Berg, J.N.; Eickholt, B.J.; Leslie, N.R. Functionally distinct groups of inherited PTEN mutations in autism and tumour syndromes. J. Med. Genet. 2015, 52, 128-134. [CrossRef] [PubMed]

13. Freeman, D.; Lesche, R.; Kertesz, N.; Wang, S.; Li, G.; Gao, J.; Groszer, M.; Martinez-Diaz, H.; Rozengurt, N.; Thomas, G.; et al. Genetic background controls tumor development in PTEN-deficient mice. Cancer Res. 2006, 66, 6492-6496. [CrossRef] [PubMed]

14. Nelen, M.R.; Padberg, G.W.; Peeters, E.A.J.; Lin, A.Y.; van den Helm, B.; Frants, R.R.; Coulon, V.; Goldstein, A.M.; van Reen, M.M.M.; Easton, D.F.; et al. Localization of the gene for Cowden disease to 10q22-23. Nat. Genet. 1996, 13, 114-116. [CrossRef] [PubMed]

15. Starink, T.M.; van der Veen, J.P.W.; Arwert, F.; de Waal, L.P.; de Lange, G.G.; Gille, J.J.P.; Eriksson, A.W. The Cowden syndrome: A clinical and genetic study in 21 patients. Clin. Genet. 1986, 29, 222-233. [CrossRef] [PubMed]

16. The National Comprehensive Cancer Network (NCCN). The NCCN guidelines genetic/familial high-risk assessment: Breast and ovarian. J. Natl. Compr. Cancer Netw. 2017, 15, 9-20. 
17. Pilarski, R.; Burt, R.; Kohlman, W.; Pho, L.; Shannon, K.M.; Swisher, E. Cowden syndrome and the PTEN hamartoma tumor syndrome: Systematic review and revised diagnostic criteria. J. Natl. Cancer Inst. 2013, 105, 1607-1616. [CrossRef] [PubMed]

18. Marsh, D.J.; Coulon, V.; Lunetta, K.L.; Rocca-Serra, P.; Dahia, P.L.M.; Zheng, Z.; Liaw, D.; Caron, S.; Duboué, B.; Lin, A.Y.; et al. Mutation spectrum and genotype-phenotype analyses in Cowden disease and Bannayan-Zonana syndrome, two hamartoma syndromes with germline PTEN mutation. Hum. Mol. Genet. 1998, 7, 507-515. [CrossRef]

19. Tan, M.H.; Mester, J.; Peterson, C.; Yang, Y.; Chen, J.L.; Rybicki, L.A.; Milas, K.; Pederson, H.; Remzi, B.; Orloff, M.S.; et al. A clinical scoring system for selection of patients for PTEN mutation testing is proposed on the basis of a prospective study of 3042 probands. Am. J. Hum. Genet. 2011, 88, 42-56. [CrossRef]

20. Mester, J.; Eng, C. Estimate of de novo mutation frequency in probands with PTEN hamartoma tumor syndrome. Genet. Med. 2012, 14, 819-822. [CrossRef]

21. Tan, W.H.; Baris, H.N.; Burrows, P.E.; Robson, C.D.; Alomari, A.I.; Mulliken, J.B.; Fishman, S.J.; Irons, M.B. The spectrum of vascular anomalies in patients with PTEN mutations: Implications for diagnosis and management. J. Med. Genet. 2007, 44, 594-602. [CrossRef] [PubMed]

22. Riegert-Johnson, D.L.; Gleeson, F.C.; Roberts, M.; Tholen, K.; Youngborg, L.; Bullock, M.; Boardman, L.A. Cancer and Lhermitte-Duclos disease are common in Cowden syndrome patients. Hered. Cancer Clin. Pract. 2010, 8, 6. [CrossRef] [PubMed]

23. Wei, G.; Zhang, W.; Li, Q.; Kang, X.; Zhao, H.; Liu, X.; Tang, X.; Wu, Y.; Han, J.; Yin, H. Magnetic resonance characteristics of adult-onset Lhermitte-Duclos disease: An indicator for active cancer surveillance? Mol. Clin. Oncol. 2014, 2, 415-420. [CrossRef] [PubMed]

24. Zhou, X.P.; Marsh, D.J.; Morrison, C.D.; Chaudhury, A.R.; Maxwell, M.; Reifenberger, G.; Eng, C. Germline inactivation of PTEN and dysregulation of the phosphoinositol-3-kinase/AKT pathway cause human Lhermitte-Duclos disease in adults. Am. J. Hum. Genet. 2003, 73, 1191-1198. [CrossRef] [PubMed]

25. Robinson, S.; Cohen, A.R. Cowden disease and Lhermitte-Duclos disease: An update. Case report and review of the literature. Neurosurg. Focus 2006, 20, E6. [CrossRef]

26. Lok, C.; Viseux, V.; Avril, M.F.; Richard, M.A.; Gondry-Jouet, C.; Deramond, H.; Desfossez-Tribout, C.; Courtade, S.; Delaunay, M.; Piette, F.; et al. Brain magnetic resonance imaging in patients with Cowden syndrome. Medicine 2005, 84, 129-136. [CrossRef] [PubMed]

27. Yakubov, E.; Ghoochani, A.; Buslei, R.; Buchfelder, M.; Eyupoglu, I.Y.; Savaskan, N. Hidden association of Cowden syndrome, PTEN mutation and meningioma frequency. Oncoscience 2016, 3, 149-155. [PubMed]

28. Brownstein, M.H.; Wolf, M.; Bikowski, J.B. Cowden's disease: A cutaneous marker of breast cancer. Cancer 1978, 41, 2393-2398. [CrossRef]

29. Hanssen, A.M.; Fryns, J.P. Cowden syndrome. J. Med. Genet. 1995, 32, 117-119. [CrossRef]

30. Bubien, V.; Bonnet, F.; Brouste, V.; Hoppe, S.; Barouk-Simonet, E.; David, A.; Edery, P.; Bottani, A.; Layet, V.; Caron, O.; et al. High cumulative risks of cancer in patients with PTEN hamartoma tumour syndrome. J. Med. Genet. 2013, 50, 255-263. [CrossRef] [PubMed]

31. Tan, M.H.; Mester, J.L.; Ngeow, J.; Rybicki, L.A.; Orloff, M.S.; Eng, C. Lifetime cancer risks in individuals with germline PTEN mutations. Clin. Cancer Res. 2012, 18, 400-407. [CrossRef]

32. Fackenthal, J.D.; Marsh, D.J.; Richardson, A.L.; Cummings, S.A.; Eng, C.; Robinson, B.G.; Olopade, O.I. Male breast cancer in Cowden syndrome patients with germline PTEN mutations. J. Med. Genet. 2001, 38, 159-164. [CrossRef]

33. Hagelstrom, R.T.; Ford, J.; Reiser, G.M.; Nelson, M.; Pickering, D.L.; Althof, P.A.; Sanger, W.G.; Coccia, P.F. Breast cancer and non-Hodgkin lymphoma in a young male with Cowden syndrome. Pediatr. Blood Cancer 2016, 63, 544-546. [CrossRef]

34. Schreibman, I.R.; Baker, M.; Amos, C.; McGarrity, T.J. The hamartomatous polyposis syndromes: A clinical and molecular review. Am. J. Gastroenterol. 2005, 100, 476-490. [CrossRef]

35. Kato, M.; Mizuki, A.; Hayashi, T.; Kunihiro, T.; Nagata, H.; Tsukada, N.; Orikasa, H.; Morinaga, S. Cowden's disease diagnosed through mucocutaneous lesions and gastrointestinal polyposis with recurrent hematochezia, unrevealed by initial diagnosis. Intern. Med. 2000, 39, 559-563. [CrossRef]

36. Heald, B.; Mester, J.; Rybicki, L.; Orloff, M.S.; Burke, C.A.; Eng, C. Frequent gastrointestinal polyps and colorectal adenocarcinomas in a prospective series of PTEN mutation carriers. Gastroenterology 2010, 139, 1927-1933. [CrossRef] 
37. Stanich, P.P.; Owens, V.L.; Sweetser, S.; Khambatta, S.; Smyrk, T.C.; Richardson, R.L.; Goetz, M.P.; Patnaik, M.M. Colonic polyposis and neoplasia in Cowden syndrome. Mayo Clin. Proc. 2011, 86, 489-492. [CrossRef]

38. Al-Thihli, K.; Palma, L.; Marcus, V.; Cesari, M.; Kushner, Y.B.; Barkun, A.; Foulkes, W.D. A case of Cowden's syndrome presenting with gastric carcinomas and gastrointestinal polyposis. Nat. Clin. Pract. Gastroenterol. Hepatol. 2009, 6, 184-189. [CrossRef]

39. Marques, M.; Ramalho, R.; Baldaque-Silva, F.; Macedo, G. Novel mutation identified in Cowden syndrome presenting as a gastric adenocarcinoma. Clin. Res. Hepatol. Gastroenterol. 2013, 37, e131-e132. [CrossRef]

40. Makis, W.; Ciarallo, A.; Hickeson, M. The use of (1)(8)f-fdg pet/ct in Cowden syndrome to differentiate multifocal gastric carcinoma from extensive benign gastric polyposis. Clin. Nucl. Med. 2012, 37, 311-314. [CrossRef]

41. Tzortzatos, G.; Aravidis, C.; Lindblom, A.; Mints, M.; Tham, E. Screening for germline phosphatase and tensin homolog-mutations in suspected Cowden syndrome and Cowden syndrome-like families among uterine cancer patients. Oncol. Lett. 2015, 9, 1782-1786. [CrossRef]

42. Mahdi, H.; Mester, J.L.; Nizialek, E.A.; Ngeow, J.; Michener, C.; Eng, C. Germline PTEN, sdhb-d, and klln alterations in endometrial cancer patients with Cowden and Cowden-like syndromes: An international, multicenter, prospective study. Cancer 2015, 121, 688-696. [CrossRef]

43. Ring, K.L.; Bruegl, A.S.; Allen, B.A.; Elkin, E.P.; Singh, N.; Hartman, A.R.; Daniels, M.S.; Broaddus, R.R. Germline multi-gene hereditary cancer panel testing in an unselected endometrial cancer cohort. Mod. Pathol. 2016, 29, 1381-1389. [CrossRef]

44. Black, D.; Bogomolniy, F.; Robson, M.E.; Offit, K.; Barakat, R.R.; Boyd, J. Evaluation of germline PTEN mutations in endometrial cancer patients. Gynecol. Oncol. 2005, 96, 21-24. [CrossRef]

45. Greene, S.L.; Thomas, J.R., 3rd; Doyle, J.A. Cowden's disease with associated malignant melanoma. Int. J. Dermatol. 1984, 23, 466-467. [CrossRef]

46. Longy, M.; Lacombe, D. Cowden disease. Report of a family and review. Ann. Genet. 1996, 39, 35-42.

47. Reifenberger, J.; Rauch, L.; Beckmann, M.W.; Megahed, M.; Ruzicka, T.; Reifenberger, G. Cowden's disease: Clinical and molecular genetic findings in a patient with a novel PTEN germline mutation. Br. J. Dermatol. 2003, 148, 1040-1046. [CrossRef]

48. Salem, O.S.; Steck, W.D. Cowden's disease (multiple hamartoma and neoplasia syndrome). A case report and review of the English literature. J. Am. Acad. Dermatol. 1983, 8, 686-696. [CrossRef]

49. American Cancer Society. Lifetime risk of developing or dying from cancer. Available online: https://www. cancer.org/cancer/cancer-basics/lifetime-probability-of-developing-or-dying-from-cancer.html (accessed on 1 May 2019).

50. Pilarski, R. Cowden syndrome: A critical review of the clinical literature. J. Genet. Couns. 2009, 18, 13-27. [CrossRef]

51. Ngeow, J.; Mester, J.; Rybicki, L.A.; Ni, Y.; Milas, M.; Eng, C. Incidence and clinical characteristics of thyroid cancer in prospective series of individuals with Cowden and Cowden-like syndrome characterized by germline PTEN, SDH, or KLLN alterations. J. Clin. Endocrinol. Metab. 2011, 96, E2063-E2071. [CrossRef]

52. Laury, A.R.; Bongiovanni, M.; Tille, J.C.; Kozakewich, H.; Nose, V. Thyroid pathology in PTEN-hamartoma tumor syndrome: Characteristic findings of a distinct entity. Thyroid 2011, 21, 135-144. [CrossRef] [PubMed]

53. Nagy, R.; Ganapathi, S.; Comeras, I.; Peterson, C.; Orloff, M.; Porter, K.; Eng, C.; Ringel, M.D.; Kloos, R.T. Frequency of germline PTEN mutations in differentiated thyroid cancer. Thyroid 2011, 21, 505-510. [CrossRef] [PubMed]

54. Pal, T.; Hamel, N.; Vesprini, D.; Sanders, K.; Mitchell, M.; Quercia, N.; Ng Cheong, N.; Murray, A.; Foulkes, W.; Narod, S.A. Double primary cancers of the breast and thyroid in women: Molecular analysis and genetic implications. Fam. Cancer 2001, 1, 17-24. [CrossRef] [PubMed]

55. Haibach, H.; Burns, T.W.; Carlson, H.E.; Burman, K.D.; Deftos, L.J. Multiple hamartoma syndrome (Cowden's disease) associated with renal cell carcinoma and primary neuroendocrine carcinoma of the skin (merkel cell carcinoma). Am. J. Clin. Pathol. 1992, 97, 705-712. [CrossRef] [PubMed]

56. Lynch, E.D.; Ostermeyer, E.A.; Lee, M.K.; Arena,J.F.; Ji, H.; Dann, J.; Swisshelm, K.; Suchard, D.; MacLeod, P.M.; Kvinnsland, S.; et al. Inherited mutations in PTEN that are associated with breast cancer, Cowden syndrome and juvenile polyposis. Am. J. Hum. Genet. 1997, 61, 1254-1260. [CrossRef] [PubMed] 
57. Shuch, B.; Ricketts, C.J.; Vocke, C.D.; Komiya, T.; Middelton, L.A.; Kauffman, E.C.; Merino, M.J.; Metwalli, A.R.; Dennis, P.; Linehan, W.M. Germline PTEN mutation Cowden syndrome: An underappreciated form of hereditary kidney cancer. J. Urol. 2013, 190, 1990-1998. [CrossRef] [PubMed]

58. Mester, J.L.; Zhou, M.; Prescott, N.; Eng, C. Papillary renal cell carcinoma is associated with PTEN hamartoma tumor syndrome. Urology 2012, 79, 1187 e1-1187 e7. [CrossRef] [PubMed]

59. Parisi, M.; Dinulos, M.B.; Leppid, K.A.; Sybert, V.P.; Eng, C.; Hudgins, L. The spectrum and evolution of phenotypic findings in PTEN mutation positive cases of Bannayan-Riley-Ruvalcaba syndrome. J. Med. Genet. 2001, 38, 52-57. [CrossRef]

60. Lachlan, K.L.; Lucassen, A.M.; Bunyan, D.; Temple, I.K. Cowden syndrome and bannayan riley ruvalcaba syndrome represent one condition with variable expression and age-related penetrance: Results of a clinical study of PTEN mutation carriers. J. Med. Genet. 2007, 44, 579-585. [CrossRef]

61. Mester, J.L.; Tilot, A.K.; Rybicki, L.A.; Frazier, T.W., 2nd; Eng, C. Analysis of prevalence and degree of macrocephaly in patients with germline PTEN mutations and of brain weight in PTEN knock-in murine model. Eur. J. Hum. Genet. 2011, 19, 763-768. [CrossRef]

62. Hansen-Kiss, E.; Beinkampen, S.; Adler, B.; Frazier, T.; Prior, T.; Erdman, S.; Eng, C.; Herman, G. A retrospective chart review of the features of PTEN hamartoma tumour syndrome in children. J. Med. Genet. 2017, 54, 471-478. [CrossRef]

63. Vanderver, A.; Tonduti, D.; Kahn, I.; Schmidt, J.; Medne, L.; Vento, J.; Chapman, K.A.; Lanpher, B.; Pearl, P.; Gropman, A.; et al. Characteristic brain magnetic resonance imaging pattern in patients with macrocephaly and PTEN mutations. Am. J. Med. Genet. A 2014, 164, 627-633. [CrossRef] [PubMed]

64. Ciaccio, C.; Saletti, V.; D’Arrigo, S.; Esposito, S.; Alfei, E.; Moroni, I.; Tonduti, D.; Chiapparini, L.; Pantaleoni, C.; Milani, D. Clinical spectrum of PTEN mutation in pediatric patients. A bicenter experience. Eur. J. Med. Genet. 2018. [CrossRef] [PubMed]

65. Balci, T.B.; Davila, J.; Lewis, D.; Boafo, A.; Sell, E.; Richer, J.; Nikkel, S.M.; Armour, C.M.; Tomiak, E.; Lines, M.A.; et al. Broad spectrum of neuropsychiatric phenotypes associated with white matter disease in PTEN hamartoma tumor syndrome. Am. J. Med. Genet. B Neuropsychiatr. Genet. 2018, 177, 101-109. [CrossRef] [PubMed]

66. Butler, M.G.; Dasouki, M.J.; Zhou, X.P.; Talebizadeh, Z.; Brown, M.; Takahashi, T.N.; Miles, J.H.; Wang, C.H.; Stratton, R.; Pilarski, R.; et al. Subset of individuals with autism spectrum disorders and extreme macrocephaly associated with germline PTEN tumour suppressor gene mutations. J. Med. Genet. 2005, 42, 318-321. [CrossRef] [PubMed]

67. Herman, G.E.; Butter, E.; Enrile, B.; Pastore, M.; Prior, T.W.; Sommer, A. Increasing knowledge of PTEN germline mutations: Two additional patients with autism and macrocephaly. Am. J. Med. Genet. 2007, 143, 589-593. [CrossRef]

68. Buxbaum, J.D.; Cai, G.; Chaste, P.; Nygren, G.; Goldsmith, J.; Reichert, J.; Anckarsater, H.; Rastam, M.; Smith, C.J.; Silverman, J.M.; et al. Mutation screening of the PTEN gene in patients with autism spectrum disorders and macrocephaly. Am. J. Med. Genet. B Neuropsychiatr. Genet. 2007, 144B, 484-491. [CrossRef] [PubMed]

69. McBride, K.L.; Varga, E.A.; Pastore, M.T.; Prior, T.W.; Manickam, K.; Atkin, J.F.; Herman, G.E. Confirmation study of PTEN mutations among individuals with autism or developmental delays/mental retardation and macrocephaly. Autism Res. 2010, 3, 137-141. [CrossRef]

70. Varga, E.A.; Pastore, M.; Prior, T.; Herman, G.E.; McBride, K.L. The prevalence of PTEN mutations in a clinical pediatric cohort with autism spectrum disorders, developmental delay, and macrocephaly. Genet. Med. 2009, 11, 111-117. [CrossRef]

71. Conti, S.; Condo, M.; Posar, A.; Mari, F.; Resta, N.; Renieri, A.; Neri, I.; Patrizi, A.; Parmeggiani, A. Phosphatase and tensin homolog $(P T E N)$ gene mutations and autism: Literature review and a case report of a patient with Cowden syndrome, autistic disorder, and epilepsy. J. Child Neurol. 2012, 27, 392-397. [CrossRef]

72. Hobert, J.A.; Embacher, R.; Mester, J.L.; Frazier, T.W., 2nd; Eng, C. Biochemical screening and PTEN mutation analysis in individuals with autism spectrum disorders and macrocephaly. EJHG 2014, 22, $273-276$. [CrossRef] [PubMed]

73. Klein, S.; Sharifi-Hannauer, P.; Martinez-Agosto, J.A. Macrocephaly as a clinical indicator of genetic subtypes in autism. Autism Res. 2013, 6, 51-56. [CrossRef] [PubMed] 
74. Rodriguez-Escudero, I.; Oliver, M.D.; Andres-Pons, A.; Molina, M.; Cid, V.J.; Pulido, R. A comprehensive functional analysis of PTEN mutations: Implications in tumor- and autism-related syndromes. Hum. Mol. Genet. 2011, 20, 4132-4142. [CrossRef] [PubMed]

75. Caliskan, A.; Kohlmann, W.K.; Affolter, K.E.; Downs-Kelly, E.; Kanth, P.; Bronner, M.P. Intramucosal lipomas of the colon implicate Cowden syndrome. Mod. Pathol. 2018, 31, 643-651. [CrossRef] [PubMed]

76. Shaco-Levy, R.; Jasperson, K.W.; Martin, K.; Samadder, N.J.; Burt, R.W.; Ying, J.; Bronner, M.P. Gastrointestinal polyposis in Cowden syndrome. J. Clin. Gastroenterol. 2017, 51, e60-e67. [CrossRef] [PubMed]

77. Levi, Z.; Baris, H.N.; Kedar, I.; Niv, Y.; Geller, A.; Gal, E.; Gingold, R.; Morgenstern, S.; Baruch, Y.; Leach, B.H.; et al. Upper and lower gastrointestinal findings in PTEN mutation-positive Cowden syndrome patients participating in an active surveillance program. Clin. Transl. Gastroenterol. 2011, 2, e5. [CrossRef] [PubMed]

78. Ngeow, J.; Heald, B.; Rybicki, L.A.; Orloff, M.S.; Chen, J.L.; Liu, X.; Yerian, L.; Willis, J.; Lehtonen, H.J.; Lehtonen, R.; et al. Prevalence of germline PTEN, BMPR1A, SMAD4, STK11, and ENG mutations in patients with moderate-load colorectal polyps. Gastroenterology 2013, 144, 1402-1409. [CrossRef]

79. Stanich, P.P.; Pilarski, R.; Rock, J.; Frankel, W.L.; El-Dika, S.; Meyer, M.M. Colonic manifestations of PTEN hamartoma tumor syndrome: Case series and systematic review. World J. Gastroenterol. 2014, 20, 1833-1838. [CrossRef]

80. Shaco-Levy, R.; Jasperson, K.W.; Martin, K.; Samadder, N.J.; Burt, R.W.; Ying, J.; Bronner, M.P. Morphologic characterization of hamartomatous gastrointestinal polyps in Cowden syndrome, peutz-jeghers syndrome, and juvenile polyposis syndrome. Hum. Pathol. 2016, 49, 39-48. [CrossRef]

81. Henderson, C.J.; Ngeow, J.; Collins, M.H.; Martin, L.J.; Putnam, P.E.; Abonia, J.P.; Marsolo, K.; Eng, C.; Rothenberg, M.E. Increased prevalence of eosinophilic gastrointestinal disorders in pediatric PTEN hamartoma tumor syndromes. J. Pediatr. Gastroenterol. Nutr. 2014, 58, 553-560. [CrossRef] [PubMed]

82. McGarrity, T.J.; Wagner Baker, M.J.; Ruggiero, F.M.; Thiboutot, D.M.; Hampel, H.; Zhou, X.P.; Eng, C. Gi polyposis and glycogenic acanthosis of the esophagus associated with PTEN mutation positive Cowden syndrome in the absence of cutaneous manifestations. Am. J. Gastroenterol. 2003, 98, 1429-1434. [CrossRef] [PubMed]

83. Kay, P.S.; Soetikno, R.M.; Mindelzun, R.; Young, H.S. Diffuse esophageal glycogenic acanthosis: An endoscopic marker of Cowden's disease. Am. J. Proctol. Gastroenterol. 1997, 92, 1038-1040.

84. Carlson, H.E.; Burns, T.W.; Davenport, S.L.; Luger, A.M.; Spence, M.A.; Sparkes, R.S.; Orth, D.N. Cowden disease: Gene marker studies and measurements of epidermal growth factor. Am. J. Hum. Genet. 1986, 38, 908-917. [PubMed]

85. Brownstein, M.H.; Mehregan, A.H.; Bilowski, J.B. Trichilemmomas in Cowden's disease. JAMA 1977, $238,26$.

86. Starink, T.M.; Hausman, R. The cutaneous pathology of facial lesions in Cowden's disease. J. Cutan. Pathol. 1984, 11, 331-337. [CrossRef]

87. Starink, T.M.; Meijer, C.J.; Brownstein, M.H. The cutaneous pathology of Cowden's disease: New findings. J. Cutan. Pathol. 1985, 12, 83-93. [CrossRef]

88. Masmoudi, A.; Chermi, Z.M.; Marrekchi, S.; Raida, B.S.; Boudaya, S.; Mseddi, M.; Jalel, M.T.; Turki, H. Cowden syndrome. J. Dermatol. Case. Rep. 2011, 5, 8-13. [CrossRef]

89. Porter, S.; Cawson, R.; Scully, C.; Eveson, J. Multiple hamartoma syndrome presenting with oral lesions. Oral Surg. Oral Med. Oral Pathol. Oral Radiol. Endod. 1996, 82, 295-301. [CrossRef]

90. Brownstein, M.H.; Mehregan, A.H.; Bikowski, J.B.; Lupulescu, A.; Patterson, J.C. The dermatopathology of Cowden's syndrome. Br. J. Dermatol. 1979, 100, 667-673. [CrossRef]

91. Fargnoli, M.C.; Orlow, S.J.; Semel-Concepcion, J.; Bolognia, J.L. Clinicopathologic findings in the Bannayan-Riley-Ruvalcaba syndrome. Arch. Dermatol. 1996, 132, 1214-1218. [CrossRef]

92. Oh, J.G.; Yoon, C.H.; Lee, C.W. Case of Cowden syndrome associated with eccrine angiomatous hamartoma. J. Dermatol. 2007, 34, 135-137. [CrossRef] [PubMed]

93. Perez-Nunez, A.; Lagares, A.; Benitez, J.; Urioste, M.; Lobato, R.D.; Ricoy, J.R.; Ramos, A.; Gonzalez, P. Lhermitte-Duclos disease and Cowden disease: Clinical and genetic study in five patients with Lhermitte-Duclos disease and literature review. Acta Neurochir. 2004, 146, 679-690. [CrossRef] [PubMed]

94. Turnbull, M.M.; Humeniuk, V.; Stein, B.; Suthers, G.K. Arteriovenous malformations in Cowden syndrome. J. Med. Genet. 2005, 42, e50. [CrossRef] [PubMed]

95. Jarrett, R.; Walker, L.; Soilleux, E.; Bowling, J. Dermoscopy of Cowden syndrome. Arch. Dermatol. 2009, 145, 508-509. [CrossRef] [PubMed] 
96. Al-Daraji, W.I.; Ramsay, H.M.; Ali, R.B. Storiform collagenoma as a clue for Cowden disease or PTEN hamartoma tumour syndrome. J. Clin. Pathol. 2007, 60, 840-842. [CrossRef]

97. Rapini, R.P.; Golitz, L.E. Sclerotic fibromas of the skin. J. Am. Acad. Dermatol. 1989, 20, 266-271. [CrossRef]

98. Trufant, J.W.; Greene, L.; Cook, D.L.; McKinnon, W.; Greenblatt, M.; Bosenberg, M.W. Colonic ganglioneuromatous polyposis and metastatic adenocarcinoma in the setting of Cowden syndrome: A case report and literature review. Hum. Pathol. 2012, 43, 601-604. [CrossRef]

99. Buisson, P.; Leclair, M.D.; Jacquemont, S.; Podevin, G.; Camby, C.; David, A.; Heloury, Y. Cutaneous lipoma in children: 5 cases with Bannayan-Riley-Ruvalcaba syndrome. J. Pediatr. Surg. 2006, 41, 1601-1603. [CrossRef]

100. Chan, O.T.; Haghighi, P. Hamartomatous polyps of the colon: Ganglioneuromatous, stromal, and lipomatous. Arch. Pathol. Lab. Med. 2006, 130, 1561-1566.

101. Ferran, M.; Bussaglia, E.; Lazaro, C.; Matias-Guiu, X.; Pujol, R.M. Acral papular neuromatosis: An early manifestation of Cowden syndrome. Br. J. Dermatol. 2008, 158, 174-176. [CrossRef]

102. Rustad, C.F.; Bjornslett, M.; Heimdal, K.R.; Maehle, L.; Apold, J.; Moller, P. Germline PTEN mutations are rare and highly penetrant. Hered. Cancer Clin. Pract. 2006, 4, 177-185. [CrossRef]

103. van der Velden, J.J.; Vreeburg, M.; Smeets, E.E.; Schrander-Stumpel, C.T.; van Steensel, M.A. Skin abnormalities in individuals with macrocephaly: Cowden disease from a dermatologist's point of view. Int. J. Dermatol. 2008, 47, 45-48. [CrossRef] [PubMed]

104. Schaffer, J.V.; Kamino, H.; Witkiewicz, A.; McNiff, J.M.; Orlow, S.J. Mucocutaneous neuromas: An underrecognized manifestation of PTEN hamartoma-tumor syndrome. Arch. Dermatol. 2006, 142, 625-632. [CrossRef]

105. Capitan Canadas, L.M.; Salinas Sanchez, J.L.; Martinez Castillo, S.L.; Labrot Moleon, I.L.; Duran Moreno, D.; Sanchez Lopez, D.; Valencia Laseca, E. Multiple oral fibropapillomatosis as an initial manifestation of Cowden syndrome. Case report. Med. Oral Patol. Oral Cir. Bucal. 2006, 11, E319-E324.

106. Vasovcak, P.; Krepelova, A.; Puchmajerova, A.; Spicak, J.; Voska, L.; Musilova, A.; Mestak, J.; Martinek, J. A novel mutation of PTEN gene in a patient with Cowden syndrome with excessive papillomatosis of the lips, discrete cutaneous lesions, and gastrointestinal polyposis. Eur. J. Gastroenterol. Hepatol. 2007, 19, 513-517. [CrossRef] [PubMed]

107. Barnhill, R.L.; Albert, L.S.; Shama, S.K.; Goldenhersh, M.A.; Rhodes, A.R.; Sober, A.J. Genital lentiginosis: A clinical and histopathologic study. J. Am. Acad. Dermatol. 1990, 22, 453-460. [CrossRef]

108. Nuss, D.D.; Aeling, J.L.; Clemons, D.E.; Weber, W.N. Multiple hamartoma syndrome (Cowden's disease). Arch. Dermatol. 1978, 114, 743-746. [CrossRef] [PubMed]

109. Okunaga, T.; Takahata, H.; Nakamura, M.; Iwasaki, K. A case report of Lhermitte-Duclos disease with systematic avms. Brain Nerve 2003, 55, 251-255. [PubMed]

110. Takaya, N.; Iwase, T.; Maehara, A.; Nishiyama, S.; Nakanishi, S.; Yamana, D.; Takei, R.; Kokubo, T.; Kohtake, H.; Furui, S.; et al. Transcatheter embolization of arteriovenous malformations in Cowden disease. Jpn. Circ. J. 1999, 63, 326-329. [CrossRef]

111. Weary, P.E.; Gorlin, R.J.; Gentry, W.C., Jr.; Comer, J.E.; Greer, K.E. Multiple hamartoma syndrome (Cowden's disease). Arch. Dermatol. 1972, 106, 682-690. [CrossRef]

112. Kurek, K.C.; Howard, E.; Tennant, L.B.; Upton, J.; Alomari, A.I.; Burrows, P.E.; Chalache, K.; Harris, D.J.; Trenor, C.C., 3rd; Eng, C.; et al. PTEN hamartoma of soft tissue: A distinctive lesion in PTEN syndromes. Am. J. Surg. Pathol. 2012, 36, 671-687. [CrossRef] [PubMed]

113. Pimpalwar, S.; Yoo, R.; Chau, A.; Ashton, D.; Margolin, J.; Iacobas, I. Temporal evolution and management of fast flow vascular anomalies in PTEN hamartoma tumor syndrome. Int. J. Angiol. 2018, 27, 158-164. [PubMed]

114. Kanada, K.N.; Merin, M.R.; Munden, A.; Friedlander, S.F. A prospective study of cutaneous findings in newborns in the united states: Correlation with race, ethnicity, and gestational status using updated classification and nomenclature. J. Pediatr. 2012, 161, 240-245. [CrossRef] [PubMed]

115. Lindsay, C.; Boardman, L.; Farrell, M. Testicular hamartomas in Cowden disease. J. Clin. Ultrasound 2003, 31, 481-483. [CrossRef] [PubMed]

116. Woodhouse, J.B.; Delahunt, B.; English, S.F.; Fraser, H.H.; Ferguson, M.M. Testicular lipomatosis in Cowden's syndrome. Mod. Pathol. 2005, 18, 1151-1156. [CrossRef] [PubMed] 
117. Woodhouse, J.; Ferguson, M.M. Multiple hyperechoic testicular lesions are a common finding on ultrasound in Cowden disease and represent lipomatosis of the testis. Br. J. Radiol. 2006, 79, 801-803. [CrossRef] [PubMed]

118. Walker, R.N.; Murphy, T.J.; Wilkerson, M.L. Testicular hamartomas in a patient with Bannayan-RileyRuvalcaba syndrome. J. Ultrasound Med. 2008, 27, 1245-1248. [CrossRef]

119. Rasalkar, D.D.; Paunipagar, B.K. Testicular hamartomas and epididymal tumor in a Cowden disease: A case report. Case. Rep. Med. 2010, 2010, 135029. [CrossRef]

120. Khan, D.; Memon, W.A.; Siddiqui, S. Testicular lipomatosis in Cowden disease. J. Ayub. Med. Coll. Abbottabad 2015, 27, 925-926.

121. Venkatanarasimha, N.; Hilmy, S.; Freeman, S. Case 175: Testicular lipomatosis in Cowden disease. Radiology 2011, 261, 654-658. [CrossRef]

122. Alnajjar, H.M.; Sahai, A.; Keane, A.; Gordon, S. Testicular pain as a presentation of Cowden syndrome. Ann. R. Coll. Surg. Engl. 2011, 93, e51-e52. [CrossRef] [PubMed]

123. Harper, M.; Arya, M.; Peters, J.L.; Buckingham, S.; Freeman, A.; O’Donoghue, E.P. Intratesticular lipoma. Scandinavian J. Urol. Nephrol. 2002, 36, 223-224. [CrossRef] [PubMed]

124. Hall, J.E.; Abdollahian, D.J.; Sinard, R.J. Thyroid disease associated with Cowden syndrome: A meta-analysis. Head Neck 2013, 35, 1189-1194. [CrossRef] [PubMed]

125. Dean, D.S.; Gharib, H. Epidemiology of thyroid nodules. Best Pract. Res. Clin. Endocrinol. Metab. 2008, 22, 901-911. [CrossRef] [PubMed]

126. Luo, J.; McManus, C.; Chen, H.; Sippel, R.S. Are there predictors of malignancy in patients with multinodular goiter? J. Surg. Res. 2012, 174, 207-210. [CrossRef] [PubMed]

127. Ahmed, R.; Al-Shaikh, S.; Akhtar, M. Hashimoto thyroiditis: A century later. Adv. Anat. Pathol. 2012, 19, 181-186. [CrossRef] [PubMed]

128. Plamper, M.; Schreiner, F.; Gohlke, B.; Kionke, J.; Korsch, E.; Kirkpatrick, J.; Born, M.; Aretz, S.; Woelfle, J. Thyroid disease in children and adolescents with PTEN hamartoma tumor syndrome (phts). Eur. J. Pediatr. 2018, 177, 429-435. [CrossRef]

129. Milas, M.; Mester, J.; Metzger, R.; Shin, J.; Mitchell, J.; Berber, E.; Siperstein, A.E.; Eng, C. Should patients with Cowden syndrome undergo prophylactic thyroidectomy? Surgery 2012, 152, 1201-1210. [CrossRef]

130. Smith, J.R.; Marqusee, E.; Webb, S.; Nose, V.; Fishman, S.J.; Shamberger, R.C.; Frates, M.C.; Huang, S.A. Thyroid nodules and cancer in children with PTEN hamartoma tumor syndrome. J. Clin. Endocrinol. Metab. 2011, 96, 34-37. [CrossRef]

131. Schrager, C.A.; Schneider, D.; Gruener, A.C.; Tsou, H.C.; Peacocke, M. Clinical and pathological features of breast disease in Cowden's syndrome: An underrecognised syndrome with an increased risk of breast cancer. Hum. Pathol. 1997, 29, 47-53. [CrossRef]

132. Sabate, J.M.; Gomez, A.; Torrubia, S.; Blancas, C.; Sanchez, G.; Alonso, M.C.; Lerma, E. Evaluation of breast involvement in relation to Cowden syndrome: A radiological and clinicopathological study of patients with PTEN germ-line mutations. Eur. Radiol. 2006, 16, 702-706. [CrossRef] [PubMed]

133. Eissing, M.; Ripken, L.; Schreibelt, G.; Westdorp, H.; Ligtenberg, M.; Netea-Maier, R.; Netea, M.G.; de Vries, I.J.M.; Hoogerbrugge, N. PTEN hamartoma tumor syndrome and immune dysregulation. Transl. Oncol. 2019, 12, 361-367. [CrossRef] [PubMed]

134. Sloot, Y.J.E.; Rabold, K.; Netea, M.G.; Smit, J.W.A.; Hoogerbrugge, N.; Netea-Maier, R.T. Effect of PTEN inactivating germline mutations on innate immune cell function and thyroid cancer-induced macrophages in patients with PTEN hamartoma tumor syndrome. Oncogene 2019. [CrossRef] [PubMed]

135. Brandmaier, A.; Hou, S.Q.; Demaria, S.; Formenti, S.C.; Shen, W.H. PTEN at the interface of immune tolerance and tumor suppression. Front. Biol. 2017, 12, 163-174. [CrossRef] [PubMed]

136. Driessen, G.J.; H, I.J.; Wentink, M.; Yntema, H.G.; van Hagen, P.M.; van Strien, A.; Bucciol, G.; Cogulu, O.; Trip, M.; Nillesen, W.; et al. Increased PI3K/Akt activity and deregulated humoral immune response in human PTEN deficiency. J. Allergy Clin. Immunol. 2016, 138, 1744-1747. [CrossRef] [PubMed]

137. Chen, H.H.; Handel, N.; Ngeow, J.; Muller, J.; Huhn, M.; Yang, H.T.; Heindl, M.; Berbers, R.M.; Hegazy, A.N.; Kionke, J.; et al. Immune dysregulation in patients with PTEN hamartoma tumor syndrome: Analysis of FOXP3 regulatory t cells. J. Allergy Clin. Immunol. 2017, 139, 607-620. [CrossRef] [PubMed] 
138. Pal, A.; Barber, T.M.; Van de Bunt, M.; Rudge, S.A.; Zhang, Q.; Lachlan, K.L.; Cooper, N.S.; Linden, H.; Levy, J.C.; Wakelam, M.J.; et al. PTEN mutations as a cause of constitutive insulin sensitivity and obesity. N. Engl. J. Med. 2012, 367, 1002-1011. [CrossRef]

139. Molfino, A.; Alessandri, F.; Mosillo, P.; Dell'Utri, D.; Farcomeni, A.; Amabile, M.I.; Laviano, A. PTEN expression and its association with glucose control and calorie supplementation in critically ill patients. Clin. Nutr. 2018, 37, 2186-2190. [CrossRef]

140. Chen, C.Y.; Chen, J.; He, L.; Stiles, B.L. PTEN: Tumor suppressor and metabolic regulator. Front. Endocrinol. 2018, 9, 338. [CrossRef]

141. Li, A.; Qiu, M.; Zhou, H.; Wang, T.; Guo, W. PTEN, insulin resistance and cancer. Curr. Pharm. Des. 2017, 23, 3667-3676. [CrossRef]

(C) 2019 by the author. Licensee MDPI, Basel, Switzerland. This article is an open access article distributed under the terms and conditions of the Creative Commons Attribution (CC BY) license (http://creativecommons.org/licenses/by/4.0/). 